\title{
HAMBATAN KELUARGA MERAWAT ANGGOTA KELUARGA DENGAN HIPERTENSI DI KELURAHAN KOLAKAASI KECAMATAAN LATAMBAGA
}

\author{
Family Barriers in Caring for Family Members with Hypertension in Kolakaasi Village, \\ Latambaga District
}

\section{Bangu 1* \\ Heriviyatno Julika Siagin \\ 2}

\author{
Tukatman $^{3}$ \\ Grace Tedy Tulak ${ }^{4}$
}

\author{
1,2,3,4 Program Studi D-III \\ Keperawatan Tiga/Fakultas \\ Sains \& Teknologi, Universitas \\ Sembilanbelas November \\ Kolaka, Indonesia \\ *email: \\ abangakper65@gmail.com
}

\begin{abstract}
Abstrak
Program Indonesia sehat adalah salah satu program Kementrian Kesehatan yang strategis melalui pendekatan keluarga agar Puskesmas dapat meningkatkan jangkauan pelayanan kesehatan di wilayahnya melalui kunjungan rumah secara aktif. Salah satu sasaran pelayanan kesehatan yang diberikan adalah penanganan penyakit tidak menular salah satunya adalah penyakit hipertensi. Hipertensi adalah penyebab utama terjadinya gangguan kardiovaskular. Bila tidak ditangani dengan serius akan menyebabkan stroke, gagal jantung, gagal ginjal, dimensia, akut miokard infak dan gangguan penglihatan. Bila factor resiko hipertensi bisa dikendalikan maka kejadian hipertensi sebenarnya dapat dicegah. Prevalensi penyakit hipertensi di Kelurahan Kolakaasi dari bulan Januari sampai Desember 2020 sebanyak 873 penderita, Berbagai hambatan yang dialami keluarga dalam memberika perawatan pada salah satu anggota keluarga yang menderita hipertensi yaitu pola hidup yang sulit dihilangkan seprti: asupan garam yang berlebihan, kebiasaan mengonsumsi daging-dagingan, kebiasaan merokok dan minum alcohol. Tujuan penelitian ini adalah untuk mengetahui hambatan yang dialami keluarga dalam merawat anggota keluarga yang menderita hipertensi.. Metode dalam penelitian ini adalah metode kualitatif dengan pendekatan fenomenologi. Hasil penelitian faktor yang menghambat keluarga dalam memberikan tindakan perawatan pada anggota keluarga dengan hipertensi, yaitu : sikap acuh tak acuh untuk berolah raga dari penbertia itu sendiri, tidak mau mengikuti penyuluhan kesehatan diposyandu/Puskesmas dan kebiasaan dari klien itu sendiri yang susah untuk dihilangkan. Kesimpulan: Kebiasaan klien/gaya hidup yang susah untuk diubah seperti kebiasaan mengonsumsi makanan asin, gorengan dan daging adalah penghambat utama keluarag dalam memberitan tindakan perawatan pada anggota keluarga yang menderit hipertesi.
\end{abstract}

Kata Kunci:

Hipertensi

Hambatan Keluarga

Gaya Hidup

\section{Keywords:}

Hypertension

Family barriers

Lifestyle

\begin{abstract}
The Healthy Indonesia Program is one of the strategic Ministry of Health programs through a family approach so that Puskesmas can increase the reach of health services in their area through active home visits. One of the targets of the health services provided is the handling of non-communicable diseases, one of which is hypertension. Hypertension is the main cause of cardiovascular disorders. If not treated seriously will cause stroke, heart failure, kidney failure, dementia, acute myocardial infarction and visual disturbances. If the risk factors for hypertension can be controlled, the incidence of hypertension can actually be prevented. The prevalence of hypertension in Kolakaasi Village from January to December 2020 was 873 sufferers. Various obstacles experienced by families in providing care for a family member who suffers from hypertension are lifestyles that are difficult to eliminate such as: excessive salt intake, the habit of consuming meat, smoking and drinking alcohol. The purpose of this study was to determine the obstacles experienced by families in caring for family members who suffer from hypertension. The method in this study was a qualitative method with a phenomenological approach. The results of the study of factors that hinder families in providing care for family members with hypertension, namely: indifferent attitude to exercise from the penbertia itself, not wanting to take part in health counseling at the Posyandu/Puskesmas and the habits of the clients themselves which are difficult to eliminate. Conclusion: The client's habits/lifestyles that are difficult to change such as the habit of consuming salty, fried and meat foods are the main obstacles for families in providing care for family members who suffer from hypertension.
\end{abstract}

(c) year The Authors. Published by Institute for Research and Community Services Universitas Muhammadiyah Palangkaraya. This is Open Access article under the CC-BY-SA License (http://creativecommons.org/licenses/by-sa/4.0/). DOI: https://doi.org/l0.33084/jsm.vxix.xxx. 


\section{PENDAHULUAN}

Program Indonesia sehat adalah salah satu program Kementrian Kesehatan yang strategis melalui pendekatan keluarga agar Puskesmas dapat meningkatkan jangkauan pelayanan kesehatan di wilayahnya melalui kunjungan rumah secara aktif. Salah satu sasaran pelayanan kesehatan yang diberikan adalah penanganan penyakit tidak menular. Kepatuhan menjalankan diet merupakan salah satu cara untuk menurunkan hipertensi sehingga dapat mengatasi dan mencegah hipertensi dan komplikasinya. Yureya Nital, Dina Oktavia2 (2017).

Puskesmas Kolakaasi mempuyai wilayah kerja 4 Kelurahan terletak di pesisir pantai toluk Bone 2 Kelurahan yaitu Kelurahan Sea dan Kolakaasi, serta 2 Kelurahan dipinggiran sungai Kolaka yaitu Kelurahan Sakuli dan Latambaga. Sebagian besar penduduk mata pencaharian adalah nelayan merupakan satu areal dalam lingkungan hidup yang sangat penting diperhatikan baik pengelolaan secara administrasi, pengelolaan habitat hidup, maupun pengelolaan sanitasi lingkungan. Kehidupan masyarakat dipesisir pantai sepanjang pinggiran sungai Kolaka mempunyai kebiasaan bakar ikan yang dicampur dengan garam berlebihan, menkosumsi minuman beralkohol (tuak) sambil merokok hal tersebut merupakan pemicu terjadinya hipertensi. Kadar lemak yang tinggi dalam darah dapat menyebabkan penyumbatan pembuluh darah sehingga menyebabkan gangguan sistem kardiovaskuler termasuk hipertensi, Andrian Patica $\mathrm{N}$ (2016).

Bila factor resiko hipertensi bisa dikendalikan maka kejadian hipertensi sebenarnya dapatdicegah. Kenaikan tekanan darah disebabkan beberapa factor antara lain: asupan garam yang berlebihan, aktifitas fisik, merokok, obesitas, minuman beralkohol, usia, stress, system renin, dan factor genetis, terdapat hubungan antara riwayat keluarga dengan kejadian hipertensi. Ranisa Andinil, Ichayuen Avianty2, Andreanda Nasution3
(2018). Penderita hipertensi tidak memperlihatkan gejalah awal tetapi sudah masuk golongan hipertensi berat, kecuali saat pemeriksaan Kesehatan secara rutin. Departemen Kesehatan RI. (20I2). Makanan kaya lemak jenuh dan kolesterol seperti daging, telur, dan produk susu dapat meningkatkan kadar kolesterol dalam tubuh dan berpengaruh pada risiko aterosklerosis dan penebalan pembuluh darah. Amilal, Janno Sinaga, Evarina Sembiring (2018).

Prevalensi hipertensi di Indonesia yang didapat melalui pengukuran pada umur $\geq 18$ tahun sebesar 25,8 persen, yang didapat melalui kuesioner terdiagnosis tenaga kesehatan sebesar 9,4 persen. Jadi prevalensi hipertensi di Indonesia sebesar 26,5 persen. Riset Kesehatan Dasar (Rikesdas) (20I3).

Prevalensi penderita hipertensi di Kelurahan Kolakaasi cukup tinggi dari bulan Januari sampai Desember 2020 sebanyak 873 penderita, Profil Puskemas Kolakaasi tahun (2020). Sehingga urgensi untuk diadakan penelitian terkait dengan hambatan Keluarga dalam memberikan perawatan penderita hipertensi. Faktor yang dapat memperbesar risiko atau kecenderungan seseorang menderita hipertensi, diantaranya ciri - ciri individu seperti umur, jenis kelamin dan suku, faktor genetik serta faktor lingkungan yang meliputi obesitas, stres, konsumsi garam, merokok, konsumsi alcohol. Anggara FHD, Prayitno N. (20I3).

Penelitian ini merupakan penelitian lanjutan tahun 2020 sebelumnya telah kami lakukan tentang Peran keluarga dalam memberikan perawatan pada penderita hipertensi dan mendapatkan hasil bahwa peran keluarga sebagai caregiver masih kurang atau belum berperan sebagaiman mestinya. Dengan alasan sibuk Seperti: Sibuk dengan pekerjaan, sering lupa, faktor malas, gaya hidup partisipan yang sulit ditinggalkan; suka makan gorengan, makan daging dan masakan asin. Bangu, Yuhanah. (2020). Berdasarkan hal tersebut maka dapat dirumuskan masalah. Apa hambatan 
keluarga dalam merawat anggota keluarga yang menderita hipertensi?

Tujuan khusus adalah untuk mengetahui hambatan yang dialami keluarga dalam memberikan tindakan perawatan pada anggota keluarga yang menderita hipertensi terkait dengan kebiasaan mengonsumsi garam, jenis makanan yang tak dapat dihindari, kebiasaan merokok dan minuman beralkohol. Spesifikasi khusus dalam penelitian adalah penelitian tentang hambatan keluarga dalam memberikan tindakan perawatan pada anggota keluarga yang menderita hipertensi di Kelurahan Kolakaasi.

Beberapa faktor yang memiliki risiko tinggi akan hipertensi seperti status gizi lebih, kebiasaan masyarakat mengonsumsi makanan bersantan yang mengandung lemak seperti ketupat, masyarakat juga cenderung memiliki kebiasaan merokok dan minuman beralkohol. Agustina, R., \& Raharjo, (B. 2015). Hipertensi disebabkan oleh beberapa faktor risiko seperti kebiasaan merokok, intake natrium yang tinggi, konsumsi makanan berlemak, kurangnya aktifitas tubuh, serta keturunan. Firmansyah, M. ,Ramadhani, (R. 2017).

\section{METODOLOGI}

Rancangan penelitian ini adalah metode kualitatif dengan pendekatan fenomenologi. Partisipan dan peneliti sebagai instrumen kunci. Populasi adalah keseluruhan penduduk yang menderita hipertensi yang berdomosili di Kelurahan Kolakaasi Januari - Desemer 2020 berjumlah 873 Orang, Januari sampai Agustus 2021 sebanyak 673 orang. Jumlah partisipan sebanyak 5 orang. Penentuan jumlah partisipan adalah saturasi data sampai titik kejenuhan, dimana tidak ada informasi baru yang didapatkan. Potter, P.A., Perry, A.G., Stockert, P.A., Hall, A.M. (20I3). Metode pelaksanaan kegiatan penelitian ini terdiri dari 2 sub bab yaitu:

\section{Alat Dan Bahan}

Perlengkapan dalam penelitian terdiri dari alat - alat : Alat tulis seperti pensil atau bolpoint, alat bantu dalam wawancara, tape recorder dan kamera. Bahan - bahan yang digunakan penelitian adalah kertas, buku catatan, map, klip, kartu dan field note.

\section{Metode Pelaksanaan}

a. Tahap Perencanaan

Tahap perencanaan persiapan penelitian ini dumilai pada bulan Maret - Mei 202I mengadakan rapat tim pelaksana persiapanpenelitian dengan pembagian tugas:

I.Tugas Ketua Peneliti:

a) Bersama - sama anggota peneliti membahas perbaikan proposal

b) Bersama anggota peneliti melaporkan kegiatan yang akan dilakukan kepada Kepala Puskesmas dan Kelurahan

c) Survey lokasi penelitian berusaha mengenal lingkunga sosial, fisik, dan keadaan alam. (Observasi Lapangan)

d) Pengumpulan data awal calon Informan

e) Pendekatan kepada calon informan

f) Penentuan informan yang akan diteliti

\section{TUGAS ANGGOTA PENELITI I:}

a) Menyiapkan semua dokumen yang dibutuhkan untuk penelitian

b) Melakukan pengumpulan data

c) Persiapan mengunggah laporan kemajuan

d) Membuat catatan kegiatan harian

e) Mendokumentasikan pelakasanaan penelitian.

\section{b.Tahap Pelaksanaan}

Tahap pelaksanaan penelitian ini dilaksanakan di Kelurahan Kolakaasi wilayah kerja Puskesmas Kolakaasi Kecamatan Latambaga pada bulan Juli sampai September 202I, dengan pembagian tugas sbb:

I. Tugas Ketua Peneliti:

a) Bersama anggota peneliti melaporkan kegiatan yang akan dilakukan kepada Kepala Puskesmas 
dan Kelurahan

b) Menentukan Jadual pelakasanaan penelitian.

c) Melakukan wawancara tak terstrukutur (unstructur interview) kepada informan yang telah ditentukan Bersama anggota peneliti (Pengumpulan Data)

d) Bersama anggota peneliti melakukan analisa data

e) Membuat laporan kemajuan penelitian

2. Tugas anggota penelitih
a) Menyiapkan semua dokumen yang dibutuhkan untuk penelitian
b) Melakukan pengumpulan data
c) Persiapan mengunggah laporan kemajuan
d) Membuat catatan kegiatan harian
e) Mendokumentasikan pelakasanaan penelitian

\section{HASIL DAN PEMBAHASAN}

Kriteria partisipan dalam penelitian ini adalah keluarga yang memiliki anggota keluarga yang menderita hipertensi > I tahun, berusia 20-60 tahun, minimal berpendidikan SD, mampu berkomunikasi dalam bahasa Indonesia dan Tidak mengalami gangguan neurologis serta bersedia menjadi partisipan.

Tabel I. Karakteristik Partisipan

\begin{tabular}{c|c|c|c|c|c|c}
\hline No & $\begin{array}{c}\text { Kode } \\
\text { Partisipan }\end{array}$ & Inisial & $\begin{array}{c}\text { Umur } \\
\text { (Tahun) }\end{array}$ & Pendidikan & Pekerjaan & $\begin{array}{c}\text { Lama anggota keluarga } \\
\text { menderita hipertensi }\end{array}$ \\
\hline I & P.I & Ny. I & 30 & SMU & IRT & 3.Tahun \\
2 & P.2 & Ny. Ar & 45 & SMP & Wiraswasta & 2. Tahun \\
3 & P.3 & Ny.H & 55 & SD & IRT & 5. Tahun \\
4 & P.4 & Ny. HR & 45 & SD & Wiraswasta & 4.Tahun \\
5 & P.5 & Ny.As. & 50 & SMP & IRT & 3. Tahun \\
\hline
\end{tabular}

Gambar I. Hambatan yang dialami keluarga dalam merawat anggota keluarga dengan hipertensi Given, B.A., Given, C.W,. \& Sherwood, R.P. (201I).

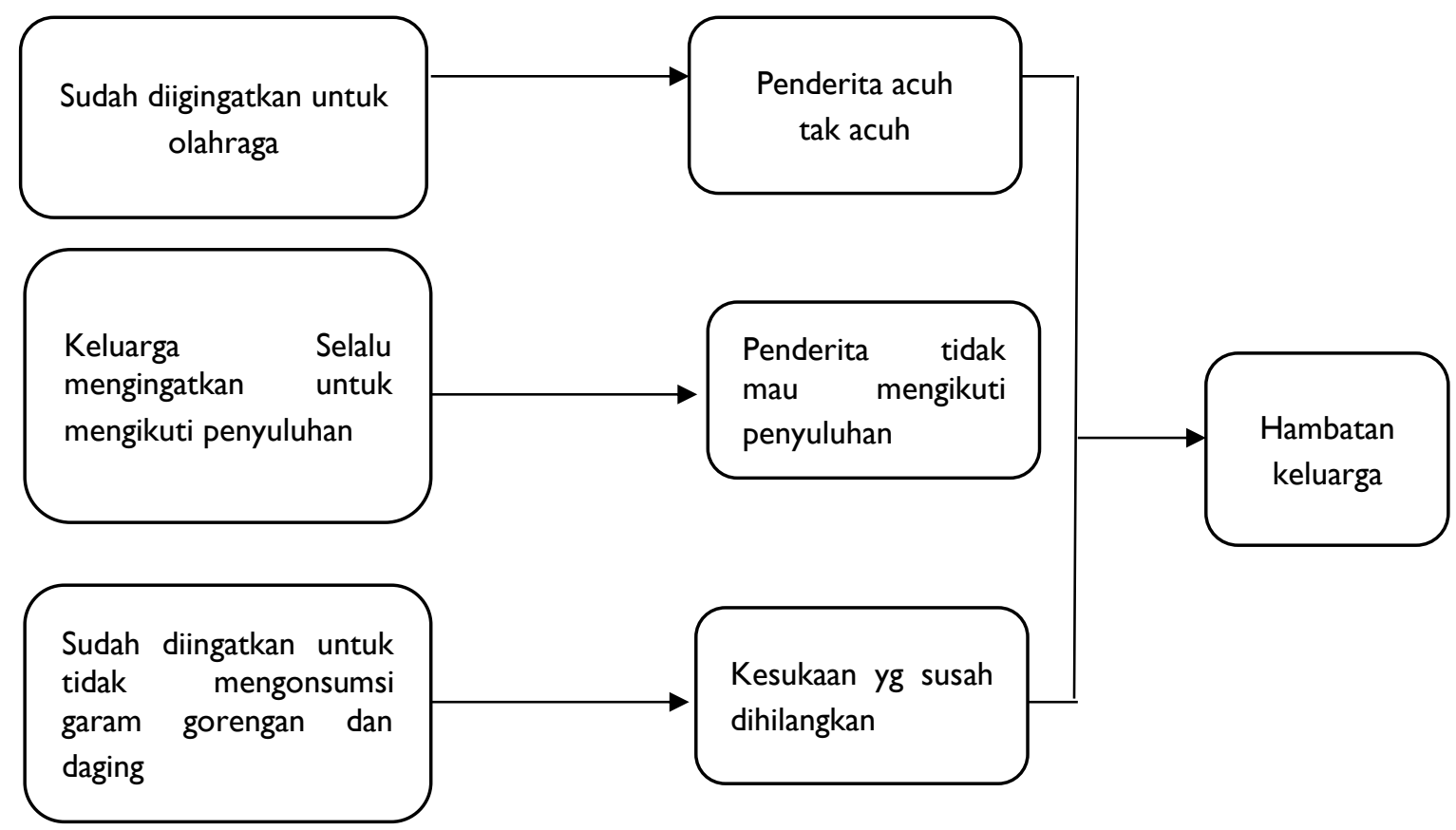


Berdasarkan hasil wawancara yang didapatkan, salah satu penyebab hambatan keluarga dalam merawat anggota keluarganya adalah sikap acuh tak acuh dari keluarga itu sendiri, seperti yang diungkapkan oleh partisipan berikut :

"Sudah diingatkan untuk olah raga, tapi penderitanya acuh atk acu antara mau dan tidak tidak mau melakukan karena cape dan sudah tua” (PI)

"Sudah diingatkan untuk olah raga, tapi penderitanya tidak mau melakukan karena merasa pusing” (P3)

"Sudah diingatkan untuk olah raga, tapi penderitanya tidak mau melakukan karena merasa tidak ada gunanya" (P4)

“Partisipan mengatakan penderita mau mengikuti ajakan untuk berolah raga yaitu jalan santai tiap pagi dan sore dihalaman rumahnya dan biasa mengikuti senam lansia tiap hari jum,at." (P5)

Partisipan juga mengungkapkan bahwa hambatan lain yang menyebabkan tidak bisa memberikan perawatan pada anggota keluarga dengan hipertensi adalah ketidak tahuan penderita tentang hipertensi. Sebagaimana yang diungkapkan partsipan sebagai berikut :

“ Partisipan sudah sering mengingatkan dan mengajak penderita untuk mengikuti penyluhan kesehatan di posyandu, penderitanya tidak mau karena sibuk.”(PI)

"Partisipan sudah mengajak penderita untuk mengikuti penyluhan kesehatan di posyandu atau Puskesmas, penderitanya tidak mau karena lama menunggu .”(P2)

"Partisipan sudah mengingatkan untuk mengikuti penyluhan kesehatan di posyandu, penderitanya tidak mau karena ribut banyak anak yang menangis.”(P4)

"Partisipan mengatakan penderita mau mengikuti ajakan untuk mengikuti penyuluhan diposyandu dan biasa mengerti tentang hipertensi." (P5)

Selain itu, terdapat pula kebiasaan yang susah dihilangkan oleh para penderita hipertensi sehingga menjadi hambatan bagi keluarga dalam memberitan tindakan perawatan pada anggota keluarga dengan hipertensi. Sebagaimana ungkapan partisipan berikut :
"Saya selalu ingatkan supaya kurangi makan makanan pantang perti: daging dan gorengan tapi penderuta tidak menghiraukan masih terus saja na makan”(PI)

"Paertisipan selalu ingatkan supaya kurangi makan makanan asin, tapi penderita tidak bisa makan kalua tawar (tidak ada rasanya) ”(P2)

"Bagaimana mau tidak naik tensinya kalau suka makan ikan asin"(P3)

"Partisipan mengatakan penderita sudah mengurangi makan manan asin, gorengan dan dagig”(P4)

Pada penelitian ini, ada beberapa faktor yang menghambat keluarga dalam memberikan tindakan perawatan pada anggota keluarga dengan hipertensi, yaitu : sikap acuh tak acuh untuk berolah raga dari penbertia itu sendiri, tidak mau mengikuti penyuluhan kesehatan diposyandu/Puskesmas dan kebiasaan dari klien itu sendiri yang susah untuk dihilangkan. Berdasarkan hasil wawancara yang dilakukan ke 5 partisipan sebahagian besar partisipan mengatakan penderita susah diajak untuk olah raga, tidak mau mengikuti penyuluhan dan kebiasan makan makanan asin dan berminyak yang sulit dihilangkan. Hanya partisipan (5) yang mau mengikuti ajakan untuk berolah raga, penderita paham tentang hipertensi serta sudah mengurangi makan makanan asin, gorengan dan daging. Penelitian yang dilakukan oleh Anggara, F.H.D., \& N. Prayitno, (20/3). Jika melakukan olahraga dengan teratur akan mudah untuk mengurangi peningkatan tekanan darah tinggi yang akan menurunkan tahanan perifer, sehigga melatih otot jantung untuk terbiasa melakuakan pekerjaan yang lebih berat karena adanya kondisi tertentu.

$\mathrm{Hal}$ tersebut diatas bertentangan dengan hasil wawancara dengan partisipan (PI) mengatakan bahwa penderia tidak mau melalukan olah raga karena cape dan sudah tua. Partisipan (P3) penderitanya tidak mau melakukan olah raga karena merasa pusing. Partisipan (P4) mengatakan penderitanya tidak mau melakukan olah raga karena merasa tidak ada gunanya. Hanya Partisipan, (P5) mengatakan penderita mau mengikuti 
ajakan untuk berolah raga yaitu jalan santai tiap pagi dan sore dihalaman rumahnya dan biasa mengikuti senam lansia tiap hari jum,at.

Tingkat pendidikan secara tidak langsung mempengaruhi tekanan darah. Tingginya resiko hipertensi pada pendidikan yang rendah, kemungkinan kurangnya pengetahuan dalam menerima informasi oleh petugas kesehatan sehingga berdampak pada perilaku atau pola hidup sehat. H Efendi, TA Larasati. (2017). Sejalan dengan penelitian ini bahwa partisipan (P2) dan (P4) mengatakan penderitanya tidan mau mengikuti penyuluhan karena lama menunggu ribut banyak anak yang menangis. Sehingga pengetahuan tentang hipertensi kurang hal tersebut termasuk factor penghambat keluarga dalam memberikan tindakan perawatan pada anggota keluarganya dengan hipertensi.

Penghambat terakhir dalam penelitian ini adalah kebiasaan klien yang susah untuk diubah seperti kebiasaan mengonsumsi makanan asin, gorengan dan daging. Menurut pendapat $\mathrm{H}$. Hadi Martono Kris Pranaka, (2014 - 20I5). Bahwa adanya peningkatan kadar sodium intraseluler dan rendahnya rasio antara potasium terhadap sodium individu sehingga pada orang tua cenderung beresiko lebih tinggi menderita hipertensi dua kali lebih besar dibandingan dengan orang yang tidak mempunyai riwayat keluarga dengan hipertensi.

\section{KESIMPULAN}

Kebiasaan klien/gaya hidup tidak peduli terhadap penyakitnya, suka makan makanan asin, gorengan dan daging adalah penghambat utama keluaraga dalam memberikan tindakan perawatan pada pasien yang menderita hipertenesi. Diharapkan partisipan dapat memberikan tindakan perawatan yang memuaskan dan menjalankan perannya sebagaimana yang diharapkan.

\section{UCAPAN TERIMA KASIH}

Proses penelitian ini telah melewati perjalanan panjang dan peneliti sepenuhnya menyadari begitu banyak kesulitan serta hambatan yang ditemukan, namun peneliti tetap berusaha semaksimal mungkin menyelesaikan penelitian ini. Sekaitan dengan itu perlu menyampaikan ucapan terima kasih dan penghargaan yang tak terhingga kepada:

I. Direktorat Sumbar Daya Direktorat Jendral Pendidikan Tinggi Kementerian Pendidikan, Kebudayaan, Riset Dan Teknologi Sebagai Pemberi Dana

2. Bapak Dr. Azhari, S.STP., M.Si selaku Rektor Universitas Sembilanbelas November Kolaka

3. Ibu Rina Rembah, ST., MT., CPHCM selaku Dekan Fakultas Sains dan teknologi Universitas Sembilanbelas November Kolaka

4. Ibu Ns. Rosani Naim, S.Kep.,M.Kep selaku Ketua Program Studi Keperawatan

\section{REFERENSI}

I. Yureya Nital, Dina Oktavia2 (2017) “Hubungan Dukungan Keluarga Terhadap Kepatuhan Diet Pasien Hipertensi di Puskesmas Payung Sekaki Pekanbaru" JURNAL ILMU KESEHATAN VOL. 6 NO. I JUNI 2018.

2. Andrian Patica N. (E-journal keperawatan volume 4 nomor I Mei 2016). Hubungan Konsumsi Makanan dan Kejadian Hipertensi pada Lansia di Puskesmas Ranomut Kota Manado.

3. Ranisa Andinil), Ichayuen Avianty2), Andreanda Nasution3) (2018) "Faktor-faktor yang berhubungan dengan kejadian hipertensi pada ibu rumah tanga di puskesmas Gang Aut Kelurahan Paledang Kecamatan Bogor Tengah Kota Bogor Tahun 2018”. PROMOTOR Jurnal Mahasiswa Kesehatan Masyarakat Vol. 2 No. I, Februari 2019.

4. Departemen Kesehatan RI. (2012). Profil Kesehatan Indonesia 2012. Jakarta : Depkes RI. [online] www.depkes.go.id, diakses tanggal 18 Oktober 2014. 
5. Amilal, Janno Sinaga, Evarina Sembiring (2018) Pencegahan stroke berulang melalui pemberdayaan Keluarga dan modifikasi gaya hidup. Fakultas Farmasi dan Ilmu Kesehatan Masyarakat, Universitas Sari Mutiara Indonesia. Jurnal ABDIMAS Vol. 22 No. 2, Desember 2018.

6. Riset Kesehatan Dasar (Rikesdas) 2013: Laporan Nasional 2013. Jakarta : Badan Penelitian dan Pengembangan Kesehatan Depkes RI [online] www.litbang.depkes.go.id, diakses tanggal 18 Oktober 2014.

7. Profil Puskemas Kolakaasi tahun (2020)

8. Anggara FHD, Prayitno N. Faktor-Faktor Yang Berhubungan Dengan Tekanan Darah Di Puskesmas Telaga Murni. Jurnal IImiah Kesehatan. 2013.

9. Bangu, Yuhanah. (2020) Peran Keluarga Dalan Merawat Anggota Keluarga Dengan Hipertensi Di Wilayah Kerja Puskesmas Kolakaasi Kelurahan Kolakaasi Kecamatan Latambaga Tahun 2020. Jurnal IImiah Kesehatan Masyarakat e-ISSN: 2579-54I4/ p- ISSN:2085-9929 Publisher: Universitas Jenderal Soedirman, Prodi. Kesehatan Masyarakat.

10. Agustina, R., \& Raharjo, B. 2015. Faktor Risiko Yang Berhubungan Dengan Kejadian Hipertensi Usia Produktif (25 - 54 Tahun). Unnes Journal of Public Health , 4(4

II. Firmansyah, M. ,Ramadhani, R. 20I7. Hubungan Merokok dan Konsumsi Kopi dengan Tekanan Darah pada Pasien Hipertensi. Jurnal Kesehatan,8(2): 263-2

12. Potter, P.A., Perry, A.G., Stockert, P.A., Hall, A.M. (20I3). Fundamentals of nursing. 8thed.St. Louis, Missouri: Elsevier Mosby

13. Given, B.A., Given, C.W,. \& Sherwood, R.P. (20II). Family \& caregiver needs over the course of the cancer trajectory. The Journal of Supportive Oncology. Di akses pada 21 desember 2016.

14. H Efendi, TA Larasati. (20I7). Dukungan Keluarga dalam Manajemen Penyakit Hipertensi. Jurnal
Majority: Fakultas Kedokteran-Universitas Lampung

I5. H. Hadi Martono Kris Pranaka. Geriatri Edisi ke5. Jakarta : FKUI ; 20I4-20I5 